\title{
Irrigation, nitrogen and sulphur fertilization response on productivity, water use efficiency and quality of Ethiopian mustard (Brassica carinata) in a semi-arid environment
}

O.P. Verma*

ICAR-Indian Institute of Water Management, Bhubaneswar -751023 (Odisha), India S. Singh

Retired principal scientist, ICAR-IARI, WTC, New Delhi - 110012, India

S. Pradhan

ICAR-Indian Institute of Water Management, Bhubaneswar -751023 (Odisha), India G. Kar

ICAR-Indian Institute of Water Management, Bhubaneswar -751023 (Odisha), India S.K. Rautaray

ICAR-Indian Institute of Water Management, Bhubaneswar -751023 (Odisha), India

*Corresponding author. E-mail: vermaop@rediffmail.com

\begin{abstract}
Water and nutrient deficiency are two major constraints that drastically affect rapeseed and mustard production under semi-arid regions of North-Western India. To cope with this problem, a study was undertaken to optimize irrigation, nitrogen and sulphur levels for productivity and quality of Ethiopian mustard(Brassica carinata).Field experiments were conducted during winter seasons of 2004-05 and 2005-06 at the Water Technology Centre (WTC), Indian Council of Agricultural Research (ICAR) - Indian Agricultural Research Institute (IARI), New Delhi, India. Irrigation, nitrogen and sulphur levels significantly $(P<0.05)$ affected plant height, LAI, siliqua weight, seeds/siliqua, test weight, seed and biomass yield of Ethiopian mustard. Application of three irrigations (seedling, $50 \%$ flowering and pod development stage) to Ethiopian mustard increased seed yield by $27-28 \%$ compared to one irrigation (seedling stage). Nitrogen @ $90 \mathrm{~kg} \mathrm{ha}^{-1}$ produced 49-54\% higher seed yield of Ethiopian mustard compared to no application. Similarly, sulphur application @ $40 \mathrm{~kg} \mathrm{ha}^{-1}$ increased seed yield by 33-34\% compared to no application of sulphur. The oil content of Ethiopian mustard was significantly $(P<0.05)$ affected by nitrogen and sulphur levels. Among the three treatments, irrigation treatment only significantly affected evapotranspiration of the studied crop. From the above study, it is suggested that application of 3 irrigations with $90 \mathrm{~kg} \mathrm{~N} \mathrm{ha}^{-1}$ and $40 \mathrm{~kg} \mathrm{~S}^{-1}$ may be practiced for achieving higher seed yield, quality and water use efficiency of Ethiopian mustard in the semi-arid environment of Northern part of India.
\end{abstract}

Keywords: Ethiopian mustard, Irrigation, Nitrogen, Sulphur, Water use efficiency

\section{Article Info}

DOI:10.31018/jans.v10i2.1741 Received: February 1, 2018

Revised: February 23, 2018

Accepted: April 5, 2018

\section{How to Cite}

Verma, O.P. et al. (2018). Irrigation, nitrogen and sulphur fertilization response on productivity, water use efficiency and quality of Ethiopian mustard (Brassica carinata) in a semi-arid environment. Journal of Applied and Natural Science, 10(2): $593-600$

\section{INTRODUCTION}

Oilseeds, the second largest agricultural commodity in India after cereals, account for nearly $5 \%$ of gross national product and $10 \%$ of the value of all agricultural products. India is the third largest producer of rapeseed and mustard having 6.7 million hectares area with 8.0 million tonnes production. Among the oilseeds, rapeseed and mustard group occupies prominent position in the country contributing nearly $21.6 \%$ of the cropped oilseed area and $23.1 \%$ of the oilseed production (DES, 2014). However, in India, its productivity is very low (1188 $\left.\mathrm{kgha}^{-1}\right)$ as compared to countries like China $\left(1872 \mathrm{kgha}^{-1}\right)$, Canada (1906 kgha $\left.{ }^{-1}\right)$ and Netherland (4160 $\left.\mathrm{kgha}^{-1}\right)$. Indian mustard (Brassica juncea) is widely grown in India and its popularity is increasing with time. But, the productivity of Indian mustard is adversely affected by biotic and abiotic stresses such as insect, pest, bacterial and fungal diseases, drought and cold (Kaur et al., 2013).Ethiopian mustard (Brassica carinata) is an alternate crop which is resistant to infestation of aphids, white rust and Alternaria blight(Malik, 1990).Because of photo-insensitive in nature, Ethiopian mustard possesses higher yield potential and yield stability under late sown conditions (Katiyar et al., 1986).Water stress and nutrient deficiency are two major constraints that influence rapeseed and mustard crop production under semi-arid regions of Northern India (Garnayak et al., 2000).

One of the primary constraints for low productivity of rapeseed and mustard is the unavailability of 
adequate irrigation water.Water stress can affect growth, development and physiological processes of the plant which can reduce biomass and ultimately grain and oil yield due to reduction of number and size of the seeds (Pradhan et al., 2014a). Increase in the amount of water supply by increasing the number of irrigations augmented the leaf water potential, stomatal conductance, light absorption, and leaf area index (LAI) which ultimately increased growth and yield attributes (Garnayak et al.,2000 andRay et al., 2015) and quality (Majid and Simpson, 1999) of mustard crop. Crops receiving only two irrigations at preflowering and pod-filling stages produced $33 \%$ more seed than non-irrigated crops. Piri et al. (2011) observed that mustard yield would increase with two irrigations at 45 and 90 days after sowing (DAS).

In addition to irrigation, lower productivity of mustard is also attributed to imbalanced and inadequate supply of nutrients. Amongst the major nutrients, nitrogen $(\mathrm{N})$ plays an important role in the growth and development of Brassica plant (Khoshanazar et al.,2000). Higher N application rates lead to rapid leaf area development, prolonged life of leaves, improved leaf area duration, increased overall crop assimilation and thus, increased seed yield (Getinet et al.,1996). Nitrogen plays a key role in plant growth and protein synthesis, protoplasm, cell size, and photosynthetic activity and thus, provides a huge frame on which more flowers and pods are produced (Yasari andPatwardhan, 2006). Nitrogen fertilizer increases yield by influencing a variety of growth parameters such as the number of branches per plant, the number of pods per plant, total plant weight and LAI. Also, it increases the number and weight of pods, seeds and flowers per plant, and overall crop assimilation, contributing to increased seed yield. Numerous attempts have been made to evaluate the optimum $\mathrm{N}$ level for production of $B$. carinata (Pramanik et al., 1996; Garnayak et al., 2000; Punia et al., 2001). They noted that the growth, seed and oil yields of $B$. carinata significantly improved with increasing $N$ rates up to 100 $\mathrm{kg} \mathrm{N} \mathrm{ha}^{-1}$ in sandy loam soils of New Delhi and Hissar.Kaur and Sidhu (2004) reported that plant height, dry matteraccumulation and seed yield of $B$. carinata were positively correlated with $\mathrm{N}$ application.Significant differences in the number of pods per plant were observed amongst the different fertilizer rates and the number of pods per plant increased linearly with increasing rates of nitrogen up to $180 \mathrm{~kg} \mathrm{~N}^{-1}$ in poor fertile sandy soils (Nielson, 1997). Oil contents per unit seed weight decreased with increasing rate of $\mathrm{N}$ application (Yasari and Patwardhan, 2006).

After N, application of sulphur (S) is known to increase yield attributes and yield of mustard (Kumar et al., 2011). It has also significant effect on chlorophyll, oil, fatty acids and synthesis of proteins (Ahmad and Abdin, 2000) and glucosinolates content in mustard seed (Falk et al., 2007). The yield and oil content were also reduced due to deficiency of this vital secondary nutrient. Both $\mathrm{N}$ and $S$ are important in oilseed crops for plant protein synthesis. Proper balance of N, P, K, and S are essential to optimize protein, oil synthesis and yield (Yasari and Patwardhan, 2006). Applying high rate of $\mathrm{N}$ without $\mathrm{S}$ can lead to lower yield compared to $\mathrm{N}$ application alone. So, it necessitates optimization of irrigation, $\mathrm{N}$ and $\mathrm{S}$ in Ethiopian mustard for maximum productivity and quality. A good amount of research pertaining to irrigation scheduling, $\mathrm{N}$ and $\mathrm{S}$ fertilization has been conducted in Indian mustard.But, a little information is available concerning response of Ethiopian mustard to irrigation levels in combination with $\mathrm{N}$ and $S$ fertilization. Keeping this in mind, the present investigation was formulated to study irrigation, nitrogen and sulphur fertilization response on productivity, water use efficiency and quality of Ethiopian mustard under semi-arid climate of Northern and North-Western India.

\section{MATERIALS AND METHODS}

Study area: The study was conducted at the research farm of ICAR-IARI, New Delhi $\left(28^{\circ} 38^{\prime} \mathrm{N}\right.$, $77^{\circ} 11^{\prime} \mathrm{E}$ and $228.6 \mathrm{~m}$ above sea level). It is characterized by semi-arid climate with dry hot summer and cold winter seasons. June is the hottest month of the year with maximum temperature ranging from 41 to $46^{\circ} \mathrm{C}$ whereas, January is coldest month of the year 2005 and 2006 with temperature falling to as low as $4^{\circ} \mathrm{C}$. The average rainfall is $683 \mathrm{~mm}$ of which about $84 \%$ falls during June to September. Only $12-15 \%$ of total annual rainfall occurs during mustard growing season (November to March). The mean daily open pan evaporation reaches as high as about $12.8 \mathrm{~mm}$ day $^{-1}$ during June and as low as about $0.6 \mathrm{~mm}$ day $^{-1}$ in January. The soil of the experimental site was sandy-loam in texture of alluvial origin (Ustocrept) with adequate internal drainage. Soil acidity/alkalinity and soil salinity problem was not encountered at the experimental site. The soil(0$120 \mathrm{~cm}$ ) of the study area was poor in organic matter (0.2-0.3 \%), low in available N (112-161 kg $\left.\mathrm{ha}^{-1}\right)$, and medium in both available $\mathrm{P}(21-23 \mathrm{~kg}$ $\left.\mathrm{ha}^{-1}\right)$ and $\mathrm{K}\left(151-185 \mathrm{~kg} \mathrm{ha}^{-1}\right)$. The bulk density varied between 1.54 to $1.56 \mathrm{~g} \mathrm{~cm}^{-3}$, the moisture content at field capacity between 7.4 to $7.7 \%$ and at permanent wilting point 16.7 to $17.6 \%$ for $0-120$ $\mathrm{cm}$ soil depth of study area. The average ground water table was below $8 \mathrm{~m}$ in both the seasons and soil water upward flux was nil.

Experimental details: The field experiments were conducted during the winter seasons of 2004-05 and 2005-06 in a split-split plot design with 3 replications. The main plot treatment consisted of 
three levels of phenology based irrigation $\left(l_{1}=\right.$ Irrigation at seedling stage, $\mathrm{I}_{2}=$ Irrigation at seedling + pod development stage and $\mathrm{I}_{3}=$ Irrigation at seedling $+50 \%$ flowering + pod development stage) and sub plots with three levels of nitrogen $\left(\mathrm{N}_{1}=30, \mathrm{~N}_{2}=60, \mathrm{~N}_{3}=90 \mathrm{~kg} \mathrm{~N}^{-1}\right)$. Three levels of sulphur $\left(S_{1}=0, S_{2}=20, S_{3}=40 \mathrm{~kg} \mathrm{~S} \mathrm{ha}^{-1}\right)$ were assigned as sub-sub plots treatment. In each irrigation, $60 \mathrm{~mm}$ water was applied with the help of Parshall flume. The gross sub plot size was 4.05 $\mathrm{m} \times 3.6 \mathrm{~m}$.An Ethiopian mustard(Brassica carinata) variety 'Pusa Gaurav' was grown in two seasons with the spacing of $45 \mathrm{~cm} \times 15 \mathrm{~cm}$ and seed rate of $4 \mathrm{~kg} \mathrm{ha}^{-1}$. This species of mustard are resistant to mustard aphids, white rust and Alternaria blight. Moreover, it is suitable for both late sown and rainfed conditions. Nitrogen through urea and DAP, sulphur through elemental sulphur were applied as per the treatment. Uniform dose of $\mathrm{P}_{2} \mathrm{O}_{5}\left(60 \mathrm{~kg} \mathrm{ha}^{-1}\right)$ through DAP and $\mathrm{K}_{2} \mathrm{O}(40 \mathrm{~kg}$ $\left.\mathrm{ha}^{-1}\right)$ through muriate of potash were applied as basal. Suitable plant protection measures were taken against mustard caterpillar at the pod formation stage of the crop. The observations recorded are plant height, LAI, number of siliqua/ plant, siliqua weight/plant,seed, stoverand biomass yield, test weight and harvest index.

Oil content (\%) in seed samples was determined by pulsed nuclear magnetic resonance (NMR) technique (Bruckel company, Minispec).Nitrogen content in stover and seed at harvest was determined by modified "Kjeldahl method" (Jackson, 1973). The S con-tent in seed and stover was determined with di-acid digesti-on by turbidity method (Jackson, 1973). The uptake of each nutrient either in stover or seed was worked out by multiplying their nutrient content with corresponding ha${ }^{1}$ treatment yield. Total nutrient uptake was obtained by summing up the amounts removed in stover and seed and was expressed in $\mathrm{kg} \mathrm{ha}^{-1}$. Soil moisture content in the profile $(0-120 \mathrm{~cm})$ was determined gravimetrically at regular intervals during the crop growth period of 2004-2005 and 2005-2006 to study the distribution and redistribution of the soil water in the profile.Seasonal Evapo -transpiration (ET) was computed using the field water balance equation (Pradhan et al., 2014a,b) as given below:

$E T=(P+I+C)-(R+D+\Delta S)$

where ET is the seasonal evapo-transpiration $(\mathrm{mm}), \mathrm{P}$ is the precipitation $(\mathrm{mm}), \mathrm{I}$ is the irrigation $(\mathrm{mm}), C$ is the capillary rise $(\mathrm{mm}), R$ is the runoff $(\mathrm{mm}), D$ is the deep percolation $(\mathrm{mm})$ and $\Delta S$ is change in profile soil moisture $(\mathrm{mm})$. As the groundwater table was very low (8-10 m depth), $C$ was assumed to be negligible. There was no runoff $(R)$ from the field plots as they were bunded to a sufficient height ( $40 \mathrm{~cm}$ height) and also no case of bund overflow was observed during the period of study. As the applied irrigation water at every time was much below the FC of the soil profile, the deep percolation out of the root zone is as considered zero.

Thus Eq. (2) simplifies to,

$\mathrm{ET}=(\mathrm{P}+\mathrm{I})-\Delta \mathrm{S}$.

Precipitation data were collected from the meteorological observatory of IARI, which is located about $1.0 \mathrm{~km}$ from the experimental plot. Irrigation was supplied through surface irrigation at critical growth stages. Changes in soil moisture content $(\Delta S)$ were calculated by gravimetric method. Water Use Efficiency (WUE) was computed as

$$
\text { WUE }=\frac{Y}{\text { EI }}
$$

The data were statistically analyzed using analysis of variance (ANOVA) as applicable to split plot design (Gomez and Gomez, 1984). The significance of the treatment effects was determined using F-test and the difference between the means were estimated using least significance difference and Duncan's multiple range tests at $5 \%$ probability level.

\section{RESULTS AND DISCUSSION}

Effect of irrigation, nitrogen and sulphur on growth: Irrigation had a significant effect $(P<0.05)$ on plant height, biomass and maximum LAl. Total above ground biomass, plant height and maximum LAI of the crop were reduced due to deficit (single) irrigation in both the years (Table 1 and 2). Three irrigations applied each at seedling, 50\% flowering and pod development stages significantly $(\mathrm{P}<0.05)$ increased the plant height, dry biomass $\left(\mathrm{qha}^{-1}\right)$ and LAl compared to one irrigation given at seedling stage. Two irrigations given at seedling and pod development stages were also significantly higher than one-irrigation but statistically at par with three irrigations (Table 1 and 2). The maximum plant height recorded were $207.8 \mathrm{~cm}$ and $204.4 \mathrm{~cm}$ in first and second year, respectively, when three irrigations were applied. The maximum LAI of 4.55 and 4.83 was obtained with three irrigations $\left(I_{3}\right)$ followed by $I_{2}$ and $I_{1}$ in the first and second years, respectively. On an average, 27.6 per cent increase in above ground biomass was obtained in $\mathrm{I}_{3}$ treatment over $\mathrm{I}_{1}$. Adequate and timely water supply to plants through irrigation and/or rainfall enhance cell turgidity and cell enlargement as well meristematic activity resulting in greater photosynthesis leading to better growth of plants (Slatyer,1967). Garnayak et al. (2000) reported an increase in growth attributes of Ethiopian mustard with increasing irrigation frequency. These findings are in agreement with Zarei (2010); Piri et al. (2011); Ray et al.(2015).

Nitrogen fertilization significantly $(P<0.05)$ increased plant height, biomass yield and maximum LAI of Ethiopian mustard up to its highest level, i.e., $90 \mathrm{~kg}$ compared to 60 and $30 \mathrm{~kg} \mathrm{ha}^{-1}$ (Table 1 and 2). The maximum DM was $90.24 \mathrm{q} \mathrm{ha}^{-1}$ in first 
Verma O.P. et al. / J. Appl. \& Nat. Sci. 10 (2): 593 - 600 (2018)

Table 1. Crop growth and yield components as influenced by irrigation, nitrogen and sulphur levels.

\begin{tabular}{|c|c|c|c|c|c|c|c|c|}
\hline \multirow[t]{2}{*}{ Treatments } & \multicolumn{2}{|c|}{ Plant height (cm) } & \multicolumn{2}{|c|}{ Maximum LAl } & \multicolumn{2}{|c|}{ Siliqua weight (g/plant) } & \multicolumn{2}{|c|}{ Seeds/Siliqua } \\
\hline & $2004-05$ & 2005-06 & $2004-05$ & 2005-06 & $2004-05$ & $2005-06$ & 2004-05 & 2005-06 \\
\hline \multicolumn{9}{|l|}{$\begin{array}{l}\text { Irrigation } \\
\text { regimes }\end{array}$} \\
\hline $\mathrm{I}_{1}$ & $161.91^{\mathrm{b}}$ & $158.50^{\mathrm{b}}$ & $2.87^{\mathrm{C}}$ & $2.52^{\mathrm{c}}$ & $14.13^{b}$ & $13.53^{c}$ & $15.65^{b}$ & $15.06^{\mathrm{b}}$ \\
\hline $\mathrm{I}_{2}$ & $197.84^{\mathrm{a}}$ & $194.26^{\mathrm{a}}$ & $3.84^{\mathrm{b}}$ & $3.80^{b}$ & $17.34^{\mathrm{a}}$ & $16.54^{\mathrm{b}}$ & $16.96^{\mathrm{a}}$ & $16.37^{\mathrm{a}}$ \\
\hline$I_{3}$ & $207.76^{\mathrm{a}}$ & $204.48^{\mathrm{a}}$ & $4.55^{\mathrm{a}}$ & $4.83^{\mathrm{a}}$ & $17.91^{\mathrm{a}}$ & $17.02^{\mathrm{a}}$ & $17.45^{\mathrm{a}}$ & $16.85^{\mathrm{a}}$ \\
\hline LSD (0.05) & 17.1 & 16.23 & 0.03 & 0.04 & 1.31 & 0.75 & 1.44 & 1.25 \\
\hline \multicolumn{9}{|l|}{ Nitrogen } \\
\hline $\mathrm{N}_{1}$ & $173.21^{\mathrm{C}}$ & $170.19^{c}$ & $2.62^{\mathrm{C}}$ & $2.58^{\mathrm{C}}$ & $12.09^{c}$ & $11.45^{\mathrm{c}}$ & $15.84^{c}$ & $15.24^{b}$ \\
\hline $\mathrm{N}_{2}$ & $191.52^{b}$ & $188.02^{b}$ & $3.77^{\mathrm{b}}$ & $3.73^{b}$ & $17.28^{b}$ & $16.54^{b}$ & $16.72^{b}$ & $16.12^{\mathrm{a}}$ \\
\hline $\mathrm{N}_{3}$ & $202.97^{\mathrm{a}}$ & $199.05^{\mathrm{a}}$ & $4.87^{\mathrm{a}}$ & $4.84^{\mathrm{a}}$ & $20.01^{a}$ & $19.21^{\mathrm{a}}$ & $17.50^{\mathrm{a}}$ & $16.91^{\mathrm{a}}$ \\
\hline LSD (0.05) & 11.45 & 11.35 & 0.05 & 0.06 & 0.82 & 0.74 & 0.69 & 0.75 \\
\hline \multicolumn{9}{|l|}{ Sulphur } \\
\hline $\mathrm{S}_{0}$ & $176.52^{\mathrm{c}}$ & $173.45^{c}$ & $2.64^{\mathrm{c}}$ & $2.61^{\mathrm{c}}$ & $14.15^{\mathrm{c}}$ & $13.38^{c}$ & $16.11^{b}$ & $15.57^{b}$ \\
\hline $\mathrm{S}_{1}$ & $190.56^{\mathrm{b}}$ & $187.20^{\mathrm{b}}$ & $3.76^{\mathrm{b}}$ & $3.73^{\mathrm{b}}$ & $16.72^{b}$ & $15.95^{\mathrm{b}}$ & $16.79^{a}$ & $16.19^{a}$ \\
\hline $\mathrm{S}_{2}$ & $200.42^{\mathrm{a}}$ & $196.59^{a}$ & $4.85^{\mathrm{a}}$ & $4.81^{\mathrm{a}}$ & $18.51^{\mathrm{a}}$ & $17.77^{\mathrm{a}}$ & $17.16^{\mathrm{a}}$ & $16.51^{\mathrm{a}}$ \\
\hline $\operatorname{LSD}(0.05)$ & 9.54 & 9.55 & 0.02 & 0.07 & 0.62 & 0.61 & 0.54 & 0.53 \\
\hline
\end{tabular}

The means with same letter are not significantly different as per the Duncan's Multiple Range Test; * ${ }^{\text {significant }}$ at $0.05 \%$ level; LAI is leaf area index

Table 2. Yield and yield components as influenced by irrigation, nitrogen and sulphur levels.

\begin{tabular}{|c|c|c|c|c|c|c|c|c|c|c|}
\hline \multirow[t]{2}{*}{$\begin{array}{l}\text { Treat- } \\
\text { ments }\end{array}$} & \multicolumn{2}{|c|}{ Seed yield (q/ha } & \multicolumn{2}{|c|}{ Stalk yield (q/ha) } & \multicolumn{2}{|c|}{$\begin{array}{l}\text { Dry biomass yield } \\
\text { at harvest }(\mathrm{q} \mathrm{ha-1})\end{array}$} & \multicolumn{2}{|c|}{ Harvest index (HI) } & \multicolumn{2}{|c|}{ Test weight (g) } \\
\hline & 2004-05 & 2005-06 & 2004-05 & 2005-06 & 2004-05 & $2005-06$ & 2004-05 & $2005-06$ & 2004-05 & 2005-06 \\
\hline \multicolumn{11}{|l|}{$\begin{array}{l}\text { Irrigation } \\
\text { regimes }\end{array}$} \\
\hline $\mathrm{I}_{1}$ & $16.04^{b}$ & $15.23^{b}$ & $53.04^{b}$ & $51.12^{b}$ & $67.0 \mathrm{~b}$ & $66.35^{b}$ & $23.00^{a}$ & $22.40^{\mathrm{a}}$ & $3.32^{\mathrm{b}}$ & $3.30^{\mathrm{b}}$ \\
\hline $\mathrm{I}_{2}$ & $19.65^{\mathrm{a}}$ & $18.49^{a}$ & $64.59^{\mathrm{a}}$ & $63.02^{\mathrm{a}}$ & $84.24^{\mathrm{a}}$ & $81.51^{\mathrm{a}}$ & $23.19^{a}$ & $22.54^{a}$ & $3.57^{\mathrm{a}}$ & $3.55^{\mathrm{a}}$ \\
\hline $\mathrm{I}_{3}$ & $20.57^{a}$ & $19.40^{\mathrm{a}}$ & $67.81^{a}$ & $66.47^{a}$ & $88.38^{\mathrm{a}}$ & $85.87^{a}$ & $23.20^{\mathrm{a}}$ & $22.50^{\mathrm{a}}$ & $3.66^{a}$ & $3.65^{a}$ \\
\hline $\begin{array}{l}\text { LSD } \\
(0.05)\end{array}$ & 1.45 & 1.25 & 5.52 & 6.19 & 4.51 & 4.68 & 3.03 & 3.19 & 0.16 & 0.20 \\
\hline \multicolumn{11}{|l|}{ Nitrogen } \\
\hline $\mathrm{N}_{1}$ & $14.63^{c}$ & $13.51^{\mathrm{c}}$ & $52.40^{c}$ & $50.53^{c}$ & $67.03^{\mathrm{c}}$ & $64.04^{c}$ & $21.77^{\mathrm{b}}$ & $21.06^{b}$ & $3.39^{b}$ & $3.37^{b}$ \\
\hline $\mathrm{N}_{2}$ & $19.83^{b}$ & $18.79^{b}$ & $64.61^{\mathrm{b}}$ & $62.67^{\mathrm{b}}$ & $84.44^{\mathrm{b}}$ & $81.46^{\mathrm{b}}$ & $23.45^{\mathrm{a}}$ & $23.04^{a}$ & $3.53^{\mathrm{a}}$ & $3.53^{\mathrm{a}}$ \\
\hline $\mathrm{N}_{3}$ & $21.81^{a}$ & $20.83^{a}$ & $68.43^{a}$ & $68.41^{a}$ & $90.24^{a}$ & $89.24^{a}$ & $24.18^{a}$ & $23.34^{a}$ & $3.63^{a}$ & $3.61^{a}$ \\
\hline $\begin{array}{l}\text { LSD } \\
(0.05)\end{array}$ & 1.03 & 0.97 & 3.74 & 3.86 & 6.57 & 4.01 & 1.18 & 1.19 & 0.13 & 0.13 \\
\hline \multicolumn{11}{|l|}{ Sulphur } \\
\hline $\mathrm{S}_{0}$ & $15.92^{c}$ & $15.06^{c}$ & $54.89^{c}$ & $53.95^{c}$ & $70.81^{c}$ & $69.01^{\mathrm{c}}$ & $22.35^{\mathrm{b}}$ & $21.71^{b}$ & $3.40^{\mathrm{b}}$ & $3.39^{b}$ \\
\hline$S_{1}$ & $19.05^{b}$ & $17.99^{b}$ & $62.17^{b}$ & $60.78^{b}$ & $81.22^{b}$ & $78.77^{b}$ & $23.40^{\mathrm{a}}$ & $22.73^{a}$ & $3.54^{\mathrm{a}}$ & $3.52^{\mathrm{a}}$ \\
\hline $\mathrm{S}_{2}$ & $21.30^{a}$ & $20.08^{a}$ & $68.48^{\mathrm{a}}$ & $66.87^{a}$ & $89.78^{a}$ & $86.95^{a}$ & $23.64^{a}$ & $23.00^{\mathrm{a}}$ & $3.61^{\mathrm{a}}$ & $3.59^{\mathrm{a}}$ \\
\hline $\begin{array}{l}\text { LSD } \\
(0.05)\end{array}$ & 0.76 & 0.73 & 2.46 & 2.34 & 3.52 & 3.30 & 0.97 & 0.89 & 0.10 & 0.10 \\
\hline
\end{tabular}

The means with same letter are not significantly different as per the Duncan's Multiple Range Test; ${ }^{*}$ significant at $0.05 \%$ level

and $82.94 \mathrm{q} \mathrm{ha}^{-1}$ in second year with $90 \mathrm{~kg} \mathrm{~N} \mathrm{ha}{ }^{-1}$, which was an increase of $34.5 \%$ and $22.3 \%$, respectively over that obtained with $30 \mathrm{~kg} \mathrm{~N} \mathrm{ha}^{-1}$. N being the constituent of amino acids, proteins and protoplast, directly influences plant growth and development through better utilization of photosynthates up to a certain level depending on the genetic potential of the crop and soil $\mathrm{N}$ availability.Kaur andSidhu (2004) reported that plant height and dry biomass of $B$. carinata was positively correlated with $\mathrm{N}$ application. Many studies have indicated that increasing $\mathrm{N}$ application significantly enhanced growth of Ethiopian mustard (Sharma et al., 2007; Pan et al., 2011).

The plant height, dry biomass, and maximum LAI were also significantly $(P<0.05)$ affected by $S$ lev- els, being highest at $40 \mathrm{~kg} \mathrm{~S} \mathrm{ha}^{-1}$ followed by 20 $\mathrm{kg}$ and no application (Table 1 and 2). The magnitude of increase in above ground biomass/plant with $40 \mathrm{~kg} \mathrm{~S} \mathrm{ha}^{-1}$ application was $21.1 \%$ and $25.9 \%$ over control in first and second years, respectively. It might be because of that $S$ is being an essential constituent of several biological active compounds like amino acids (Cystine, cysteine and methionine), vitamins (Thiamine and Biotin) lipoic acid, acetyl Co-A, Ferrodoxin and glutathione-S play multiple roles in the plant metabolism. It engages in activation of a number of enzymes participating in dark reaction of photosynthesis via improvement in chlorophyll content of leaves (Aulakh and Patel, 1991). The increased uptake of nutrients in general and their activation 
Verma O.P. et al. / J. Appl. \& Nat. Sci. 10 (2): 593 - 600 (2018)

Table 3. Mean $\mathrm{N}$ and $\mathrm{S}$ content in seeds/ stalk and their uptake as influenced by irrigation, nitrogen and sulphur levels.

\begin{tabular}{|c|c|c|c|c|c|c|c|c|}
\hline \multirow[t]{2}{*}{ Treatments } & \multicolumn{2}{|c|}{ N-Seed (\%) } & \multicolumn{2}{|c|}{ N-Stover (\%) } & \multicolumn{2}{|c|}{$\mathrm{N}$-uptake $\left(\mathrm{kg} \mathrm{ha}^{-1}\right)$} & \multicolumn{2}{|l|}{ Oil (\%) } \\
\hline & 2004-05 & 2005-06 & 2004-05 & 2005-06 & 2004-05 & 2005-06 & 2004-05 & 2005-06 \\
\hline \multicolumn{9}{|l|}{$\begin{array}{l}\text { Irrigation } \\
\text { reqimes }\end{array}$} \\
\hline $\mathrm{I}_{1}$ & $3.35^{b}$ & $3.34^{b}$ & $0.34^{b}$ & $0.31^{b}$ & $72.30^{c}$ & $68.69^{b}$ & $37.14^{\mathrm{a}}$ & $36.56^{a}$ \\
\hline $\mathrm{I}_{2}$ & $3.50^{\mathrm{a}}$ & $3.51^{\mathrm{a}}$ & $0.35^{a}$ & $0.34^{a}$ & $92.47^{b}$ & $87.37^{\mathrm{a}}$ & $37.76^{a}$ & $37.32^{\mathrm{a}}$ \\
\hline $\mathrm{I}_{3}$ & $3.51^{a}$ & $3.53^{a}$ & $0.35^{a}$ & $0.34^{a}$ & $96.97^{a}$ & $91.83^{a}$ & $37.94^{a}$ & $37.50^{\mathrm{a}}$ \\
\hline LSD (0.05) & 0.20 & 0.21 & 0.022 & 0.019 & 6.60 & 6.88 & 2.20 & 2.59 \\
\hline \multicolumn{9}{|l|}{ Nitrogen } \\
\hline $\mathrm{N}_{1}$ & $3.28^{c}$ & $3.30^{c}$ & $0.33^{c}$ & $0.32^{b}$ & $65.89^{b}$ & $61.33^{c}$ & $38.36^{a}$ & $37.97^{a}$ \\
\hline $\mathrm{N}_{2}$ & $3.47^{b}$ & $3.40^{\mathrm{b}}$ & $0.35^{b}$ & $0.34^{a}$ & $91.83^{a}$ & $87.25^{\mathrm{b}}$ & $37.45^{\mathrm{ab}}$ & $36.91^{\mathrm{ab}}$ \\
\hline $\mathrm{N}_{3}$ & $3.61^{a}$ & $3.60^{\mathrm{a}}$ & $0.36^{a}$ & $0.34^{a}$ & $103.87^{a}$ & $99.28^{a}$ & $37.05^{\mathrm{b}}$ & $36.52^{\mathrm{b}}$ \\
\hline LSD (0.05) & 0.12 & 0.12 & 0.012 & 0.013 & 7.15 & 6.86 & 1.25 & 1.33 \\
\hline \multicolumn{9}{|l|}{ Sulphur } \\
\hline $\mathrm{S}_{0}$ & $3.36^{b}$ & $3.37^{b}$ & $0.33^{b}$ & $0.32^{b}$ & $72.67^{c}$ & $69.04^{c}$ & $35.75^{\mathrm{c}}$ & $35.19^{c}$ \\
\hline $\mathrm{S}_{1}$ & $3.47^{\mathrm{a}}$ & $3.48^{a}$ & $0.35^{a}$ & $0.34^{a}$ & $88.73^{b}$ & $84.13^{b}$ & $37.90^{\mathrm{b}}$ & $37.39^{b}$ \\
\hline & $3.52^{a}$ & $3.53^{\mathrm{a}}$ & $0.35^{\mathrm{a}}$ & $0.34^{a}$ & $100.21^{a}$ & $94.70^{\mathrm{a}}$ & $39.20^{\mathrm{a}}$ & $38.82^{\mathrm{a}}$ \\
\hline $\operatorname{LSD}(0.05)$ & 0.10 & 0.11 & 0.009 & 0.009 & 4.89 & 4.87 & 1.15 & 1.19 \\
\hline
\end{tabular}

The means with same letter are not significantly different as per the Duncan's, Multiple Range Test; * significant at $0.05 \%$ level

Table 4. Evapo-transpiration and water use efficiency of mustard as influenced by irrigation, nitrogen and Sulphur.

\begin{tabular}{|c|c|c|c|c|c|c|}
\hline \multirow[t]{2}{*}{ Treatments } & \multicolumn{3}{|l|}{ ET (mm) } & \multicolumn{3}{|c|}{ Water use efficiency $\left(\mathrm{kg} \mathrm{ha}^{-1} \mathrm{~mm}^{-1}\right)$} \\
\hline & 2004-05 & 2005-06 & Mean & 2004-05 & 2005-06 & Mean \\
\hline \multicolumn{7}{|l|}{ Irrigation regimes } \\
\hline $\mathrm{I}_{1}$ & $233^{c}$ & $226^{\mathrm{c}}$ & $229^{c}$ & 6.27 & 6.73 & 6.50 \\
\hline $\mathrm{I}_{2}$ & $272^{\mathrm{b}}$ & $270^{\mathrm{b}}$ & $271^{b}$ & 7.29 & 6.84 & 7.06 \\
\hline $\mathrm{I}_{3}$ & $308^{a}$ & $297^{a}$ & $303^{a}$ & 7.08 & 6.53 & 6.80 \\
\hline LSD (0.05) & 0.90 & 1.0 & & & & \\
\hline \multicolumn{7}{|l|}{ Nitrogen } \\
\hline $\mathrm{N}_{1}$ & $269^{a}$ & $263^{a}$ & $266^{a}$ & 5.96 & 5.13 & 5.50 \\
\hline $\mathrm{N}_{2}$ & $271^{a}$ & $264^{a}$ & $268^{a}$ & 7.25 & 7.11 & 7.18 \\
\hline$N_{3}$ & $273^{a}$ & $265^{a}$ & $269^{a}$ & 7.53 & 7.85 & 7.69 \\
\hline LSD $(0.05)$ & 0.08 & 0.09 & & & & \\
\hline \multicolumn{7}{|l|}{ Sulphur } \\
\hline $\mathrm{S}_{0}$ & $270^{a}$ & $263^{a}$ & $267^{a}$ & 5.89 & 5.72 & 5.80 \\
\hline$S_{1}$ & $271^{a}$ & $264^{a}$ & $268^{a}$ & 7.02 & 6.81 & 6.91 \\
\hline $\mathrm{S}_{2}$ & $271^{a}$ & $265^{a}$ & $268^{a}$ & 7.85 & 7.57 & 7.71 \\
\hline LSD(0.05) & 0.11 & 0.13 & & & & \\
\hline
\end{tabular}

The means with same letter are not significantly different as per the Duncan's Multiple Range

at cellular level by promoting greater photosynthetic and meristemetic activity seemed to have stimulated vegetative growth of mustard in terms of plant height, branching and biomass. Increase in mustard growth with an increase in rate of $S$ application has also been reported by several workers (Pan et al., 2011; Piri et al., 2012).

Effect of irrigation, nitrogen and sulphur on yield and yield attributes: Application of three irrigations each at seedling, $50 \%$ flowering and pod development stages significantly $(P<0.05)$ increased the yield attributes (seeds/siliqua, siliquae weight/plant and 1000-seed weight, seed and biomass yield of mustard) compared to one irrigation, given at seedling stage (Table 1 and 2). Irrigation applied thrice (seedling $+50 \%$ flowering + pod development stages of crop growth) in- creased the seed yield by $27.8 \%$ and $30 \%$ over one irrigation (seedling stage) in 2004-05 and 2005-06, respectively. Similarly, 2 irrigations increased the yield by 21.8 and $23.3 \%$ over one irrigation in both the years. It was because of most of the yield attributes were increased in commensurate with irrigation. The siliqua weight was increased significantly under 3 irrigations over 1 irrigation, attained a maximum of 17.91 and 17.62 $\mathrm{g}$ plant $^{-1}$ under 3 irrigations in the first and second year, respectively. Similarly, the seeds per siliqua did not vary significantly between 2 and 3 irrigations but significantly reduced in one irrigation over three irrigations. However, the harvest index did not vary significantly $(\mathrm{P}<0.05)$ among irrigation treatments. The available water in soil is one of the most important factors for increasing crop yields 
Verma O.P. et al. / J. Appl. \& Nat. Sci. 10 (2): 593 - 600 (2018)

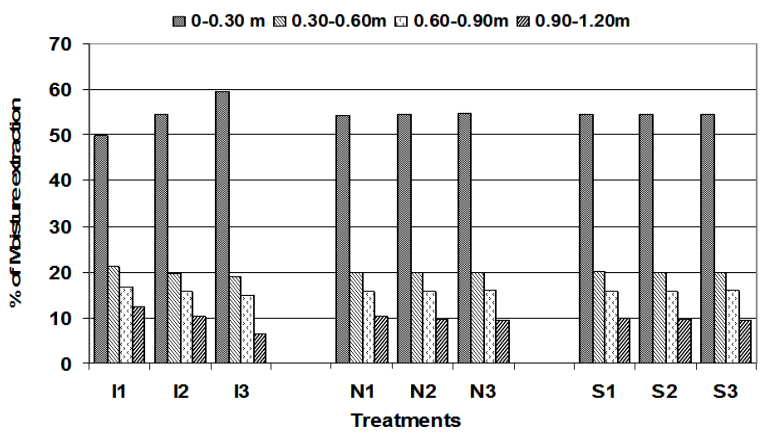

Fig.1. Moisture extraction pattern by the Ethiopian mustard crop in different soil layers.

(Ghooshchi et al.,2008). The availability of adequate moisture in soil during critical growth stages (seedling, flowering and siliqua deve-lopment) might have enabled the plants to attain a greater biomass, thereby increasing yield of the crop (Pramaniket al., 1996; Garnayak et al., 2000; Piri et al., 2011; Shabani et al., 2013; Ray et al., 2015).

Nitrogen application up to its highest level $(90 \mathrm{~kg}$ $\mathrm{ha}^{-1}$ ) increased seed and harvested biomass yields significantly (Table 1 and 2 ) as it increased the number of primary branches and siliquae per plant at harvest significantly. Increase in seed yield with $90 \mathrm{~kg} \mathrm{~N} \mathrm{ha}^{-1}\left(\mathrm{~N}_{3}\right)$ application over the 30 $\mathrm{kg} \mathrm{ha}^{-1}\left(\mathrm{~N}_{1}\right)$ was $30.6 \%$ and $54.1 \%$ in the first year and second years, respectively. Nitrogen is being the constituent of protein and protoplasm would naturally increase seed yield of Brassica principally through formation of greater potential sites for pod formation as a result of enhanced growth, branching and also decreased abscission rate of flowers. Kaur and Sidhu (2004) observed that seed yield of $B$. carinata was positively correlated with increasing $\mathrm{N}$ application. Response of Brassica carinata to higher dose of $\mathrm{N}$ up to $90 \mathrm{~kg} \mathrm{~N} \mathrm{ha}^{-1}$ was obtained (Pramanik et al., 1996; Puniaet al.,2001; Garnayak et al.,2000; Sharma et al., 2007; Pan et al., 2011and 2012; Johnson et al., 2013).

The number of primary branches and siliquae per plant, seed and dry biomass yield of Ethiopian mustard enhanced significantly $(P<0.05)$ with the increase in levels of applied $S$ up to $40 \mathrm{~kg} \mathrm{ha}^{-1}$ but harvest index, seeds/siliqua and test weight up to $20 \mathrm{~kg} \mathrm{~S} \mathrm{ha}^{-1}$ in both the years (Table 1 and 2). Increase in seed yield with the application of 20 and $40 \mathrm{~kg} \mathrm{~S} h a^{-1}$ over the control was 19.7 and $33.8 \%$ in the first year and 19.5 and $33.3 \%$ in the second year, respectively. The increase in yield attributes might be due to that application of $S$ improved over all nutritional environments of the rhizosphere as well as in the plant system, which in turn enhanced the plant metabolism and photosynthetic activity. This resulted in to better growth and development of plants and ultimately reflected in better yield traits. The cumulative effect of yield attributes leads to higher seed yield under successive increase of $S$ levels up to $40 \mathrm{~kg} \mathrm{ha}^{-1}$. The increase in siliqua weight was owing to production of well-developed siliqua, assimilating higher dry matter into the siliqua under the influence of $S$ application. The increment in harvest index due to increased levels of $S$ (up to $20 \mathrm{~kg} \mathrm{ha}^{-1}$ ) might be the result of increased translocation of photosynthates to sink. Sulphur fertilization with $40 \mathrm{~kg} \mathrm{ha}^{-1}$ was more efficient than $20 \mathrm{~kg} \mathrm{Sha}^{-1}$ in inc-reasing the seed yield which might be supplemented with increased number of yield attributes of mustard (Kumar et al., 2011; Kumar and Trivedi, 2012; Piri, 2012; Ray et al., 2015).

\section{Quality parameters}

Impact of irrigation, nitrogen and sulphur on oil content: The oil content of the seed was not significantly $(P<0.05)$ influenced by irrigation regimes for both the seasons. Oil content was negatively related with the amount of $\mathrm{N}$ application. At $\mathrm{N}_{1}\left(30 \mathrm{~kg} \mathrm{ha}^{-1}\right), 38.36 \%$ oil was obtained whereas $37.01 \%$ oil was obtained with $\mathrm{N}_{3}$ treatment. Decrease in oil content of Ethiopian mustard due to $\mathrm{N}$ application was reported by Garnayak et al. (2000). These results are consistent with the findings published by Kaur andSidhu (2006). The data on oil content (Table 3 ) showed that significant differences were manifested in the oil content of seeds due to sulphur application. In 2004-05, the treatment receiving $40 \mathrm{~kg} \mathrm{~S}^{-1}$ resulted in the maximum oil content (39.2\%) and significantly superior over $20 \mathrm{~kg} \mathrm{~S} \mathrm{ha}^{-1}(37.90 \%)$ and control (35.75\%). The oil content with 0, 20, $40 \mathrm{~kg} \mathrm{~S} \mathrm{ha}$ ${ }^{1}$ application was $35.18 \%, 37.34 \%$ and $38.82 \%$, respectively, in 2005-06. This might be due to role of $S$ in synthesis of oil. Sulphur is involved in the formation of glucosides and glucosinolates (mustard oil) and sulphydril-linkage and activation of enzymes which aid in biochemical reaction within the plant. Earlier research work also showed that successive increase in S-levels on mustard led to increase in oil content (Kumar andTrivedi, 2012; Ray et al., 2015).

Impact of irrigation, nitrogen and sulphur on $\mathbf{N}$ content in seed, stover and its uptake: Nitrogen content in both seed and stalk was found significantly $(P<0.05)$ more when plants receiving three irrigations $\left(I_{3}\right)$ as compared to single irrigation. The two or 3 irrigations were statistically similar in their effect. Irrigation progressively and significantly increased the $\mathrm{N}$ uptake in seeds and stalk in both the seasons (Table 3). Maximum N uptake (96.9 $\mathrm{kg} \mathrm{ha}^{-1}$ in 2004-05 and $91.8 \mathrm{~kg} \mathrm{ha}^{-1}$ in 2005-06) in seed and stalk was recorded with 3 irrigations followed by 2 irrigations $\left(I_{2}\right)$ and the least with one irrigation $\left(I_{1}\right)$. Irrigation applied at three stages of mustard growth resulted in significantly total higher $\mathrm{N}$ uptake than two irrigations followed by one irrigation. Irrigation increased significantly N content and its uptake in plants parts commensurate 
with the increased frequency as it enhanced the seed and biomass productivity. Increase in $\mathrm{N}$ uptake due to irrigation was also reported by several other workers (Garnayak et al., 2000; Pan et al., 2011).

Application of $\mathrm{N}$ progressively and significantly $(P<0.05)$ increased $N$ uptake in seeds and stalk up to the highest level, i.e., $90 \mathrm{~kg} \mathrm{ha}^{-1}$. Application of $90 \mathrm{~kg} \mathrm{~N} \mathrm{ha}^{-1}$ recorded the maximum $\mathrm{N}$ uptake followed by 60 and $30 \mathrm{~kg} \mathrm{~N} \mathrm{ha}^{-1}$. Total nitrogen uptake in plants increased progressively and significantly with each additional $\mathrm{N}$ dose up to 90 $\mathrm{kg} \mathrm{ha}^{-1}$. At this level, its value was higher by about $56.6 \%$ in $2004-05$ and by $61.9 \%$ in $2005-06$ over $30 \mathrm{~kg} \mathrm{~N} \mathrm{ha}^{-1}$ (Table 3). Amount of $\mathrm{N}$ harvested in stalk and seed as well as whole plant was improved as more fertilizer $\mathrm{N}$ was added (up to 90 $\mathrm{kg} \mathrm{N} \mathrm{ha}^{-1}$ ). It is probably because not only $\mathrm{N}$ concentration in them, but also their yields were increased. The Ethiopian mustard utilized applied $\mathrm{N}$ more efficiently because of its deep and betterdeveloped root system associated with its longer duration as well as more vigorous and robust growth of above ground parts. This would help to absorb more $\mathrm{N}$ from the profile and utilize it more efficiently. Several workers reported that $\mathrm{N}$ application increased $\mathrm{N}$ uptake in rapeseed and mustard (Garnayak et al., 2000; Johnson et al., 2013). Crop fertilized with $40 \mathrm{~kg} \mathrm{~S}^{-1} \mathrm{ha}^{-1}$ removed significantly $(\mathrm{P}<0.05)$ higher amount of $\mathrm{N}$ in seed,stalk as well as in whole plant followed by $20 \mathrm{~kg} \mathrm{~S} \mathrm{ha}^{-1}$ and no sulphur application in that order, respectively in both the years. At this level, the total $\mathrm{N}$ uptake was higher by about $37.8 \%$ in 2004-05 and by $37 \%$ in $2005-06$, respectively over control. Sulphur fertilization increased $\mathrm{N}$ concentration in seed and stalk and their uptake (Table 3). Sulphur application might have improved the nutritional environment in the rhizosphere as well as in the plant system, consequently leading to increased availability of nitrogen in the root zone. The increased metabolic activity at cellular level might have influenced translocation, especially $\mathrm{N}$ to reproductive parts (sinks) that ultimately might have increased the concentration of $\mathrm{N}$ in different plant parts including seed. Since, $\mathrm{N}$ uptake is the function of seed and stalk yields and their $\mathrm{N}$ concentration. The significant improvement in both seed and stalk yields due to application of $S$ might have enhanced $\mathrm{N}$ uptake significantly in Ethiopian mustard. Earlier studies also showed that successive increase in S-levels on mustard led to increased S uptake (Sharma et al. 2007; Kumar andTrivedi,2012; Ray et al., 2015).

Water extraction pattern and crop water use efficiency: Crop water use and water use efficiency of Ethiopian mustard as influenced by irrigation, nitrogen and sulphur were also worked out and are presented in Table 6 . Pooled data of two years (2004-05 and 2005-06) revealed that crop water use of 229, 271 and $303 \mathrm{~mm}$ were recorded by the crop under $I_{1}, I_{2}$ and $I_{3}$, irrigation treatments, respectively, which was significantly different. The crop water uses among different nitrogen and sulphur treatments were not significantly different. The mean WUE of mustard was 7.29 and $6.84 \mathrm{~kg} \mathrm{ha}^{-1} \mathrm{~mm}^{-1}$ for the year 2004-05 and 200506, respectively (Table 4) which is in agreement with Pan et al. (2011) and Pradhan et al.(2014). Based on profile soil moisture use, the soil moisture extraction patterns at different depths were worked out (Fig. 1). Study revealed that $49.5 \%$, $54.5 \%$ and $59.8 \%$ soil moisture was extracted by the crop at $0-0.30 \mathrm{~m}$ depth under $\mathrm{I}_{1}, \mathrm{I}_{2}, \mathrm{I}_{3}$ irrigation treatments, respectively. In different nitrogen and sulphur treatments, about $55 \%$ of total moisture was extracted in this layer. The next layer $(0.30$ $0.60 \mathrm{~m}$ ) extracted about $20 \%$ of total soil moisture by almost all the treatments.

\section{Conclusion}

Application of three irrigations (seedling, 50\% flowering and pod development stages) and $90 \mathrm{~kg}$ $\mathrm{N}$ ha $^{-1}$ significantly $(\mathrm{P}<0.05)$ increased the plant height, leaf area index, yield attributes (number of seeds/siliqua and siliquae weight/plant), seed, biomass yield and harvest index of Ethiopian mustard (Brassica carinata). Increase in S levels were also significantly improved the growth, yield attributes, seed and biomass yield of mustard. The highest seed and harvested biomass yield were obtained with $40 \mathrm{~kg} \mathrm{~S} \mathrm{ha}^{-1}$. Oil content was negatively related with the amount of $\mathrm{N}$ application. Significant differences were manifested in the oil content of seeds due to $S$ application, but not due to irrigation. The mean WUE of mustard was 7.29 and $6.84 \mathrm{~kg} \mathrm{ha}^{-1} \mathrm{~mm}^{-1}$ for the year 2004-05 and 2005-06, respectively. From the above study it issuggested that application of 3 irrigations with 90 $\mathrm{kg} \mathrm{Nha}^{-1}$ and $40 \mathrm{~kg} \mathrm{Sha}^{-1}$ fertilizers may be practiced for achieving higher seed yield, quality and water use efficiency of Ethiopian mustard in the semi-arid environment of North and NorthWestern part of India.

\section{REFERENCES}

Ahmad, A. and Abdin, M.Z.(2000). Effect of sulphur application on lipid, RNA and fatty acid content in developing seeds of rapeseed (Brassica campestris L.). Plant Sci., 150: 71-76.

Aulakh, M.S. and Patel, M.S. (1991). Soil related constraints and management for oilseed and pulse production in India. B. Indian Soc. Soil Sci., 15: 129144.

DES. (2014). Directorate of Economics \& Statistics, Department of Agriculture \& Cooperation,p. 77.

Falk, K.L., Tokuhisa, J.G. and Gershenzon, J. (2007). The effect of sulfur nutrition on plant glucosinolate content: Physiology and molecular mechanisms. Plant Biol., 9: 573-581.

Garnayak, L.M., Singh, N.P., Subedar Singh, Paikaray, 
R.K. and Singh, S. (2000). Influence of irrigation and nitrogen on growth, yield and nutrient uptake by the late sown Brassica oilseeds. Indian J. Agron., 45:371 $-378$.

Getinet, A., Rakow, G. Roney, J.P. and Downey, R.K. (1996). Agronomic performance and seed quality of Ethiopian mustard in Saskatchewan.Can. J. Plant Sci., 76:387-392.

Ghooshchi, F., Seilsepour, M. and Jafari, P. (2008). Effects of water. Am-Eurasian J. Agric. Environ. Sci.,4: 302-305.

Gomez, K.A. and Gomez, A.A. (1984). Statistical procedures for Agricultural Research. John Wiley \& Sons, New York.

Jackson, M.L. (1973). Soil Chemical Analysis, Prentice Hall of India Private Limited, New Delhi, p. 187.

Johnson, E.N., Malhi, S.S., Hall, L.M. and Phelps, S. (2013). Effects of nitrogen fertilizer application on seed yield, $\mathrm{N}$ uptake, $\mathrm{N}$ use efficiency, and seed quality of Brassica carinata. Can. J. Plant Sci.,93: 1073-1081.

Katiyar, R.K., Gangasaran, and Giri, G. (1986). Evaluation of Brassica carinata as a new oilseed crop in India. Exp. Agr., 22: 67-70.

Kaur, P. and Sidhu, M.S.(2006). Effect of sowing date, nitrogen level and row spacing on oil quality of Ethiopian mustard. Environ. Ecol., 24: 1112-1114.

Kaur, P. and Sidhu, M.S.(2004). Effect of sowing date, nitrogen level and row spacing on the growth and yield of African sarson (Brassica carinata A. Braun). J. Res. Punjab Agric. University, 41: 27-34.

Kaur, R.D., Yadav, R.C. Yadav, N. R., Rani, A., Saini. P.and Singh, D. (2013). In vitro plant regeneration from anthers of Indian mustard. Cruciferae Newslett., 32: 8-10.

Khoshanazar, P.R., Ahmadi, M.R. and Ghanndha, M.R. (2000). A study of adaptation and yield capacity of rapeseed (Brassica napus L.) cultivars and lines. Iranian J. Agri. Sci.,31: 341-352.

Kumar, R. and Trivedi, S.K. (2012). Effect of levels and sources of sulphur on yield, quality and nutrient uptake by mustard (Brassica juncea). Prog. Agr.-An IntI J.,12: 69-73.

Kumar, S., Verma, S.K., Singh. T.K. and Singh, S. (2011). Effect of nitrogen and sulphur on growth, yield and nutrient uptake by Indian mustard (Brassica juncea). Indian J. Agric. Sci., 81: 145-149.

Majid, A. and Simpson, G.M. (1999). Yield and quality of mustard (Brassica juncea L.) as affected by irrigation pattern. Pakistan J. Soil Sci. 16: 5-10.

Malik, R.S. (1990). Prospects for Brassica carinata as an oilseed crop in India. Exp. Agr., 26: 125-129.

Nielson, D.C. (1997).Water use and yield of canola under dry land conditions in the central Great Plains. J. Prod. Agric., 10: 307-313

Pan, X., Lada, R.R., Caldwell, C.D. andFalk, K.C.
(2011). Water-stress and N-nutrition effects on photosynthesis and growth of Brassica carinata. Photosynthetica, 2, 309-315.

Pan, X., Caldwell, C.D., Falk, K.C. and Lada, R. (2012). The effect of cultivar, seeding rate and applied nitrogen on Brassica carinata seed yield and quality in contrasting environments. Can J. Plant Sci., 92: $961-$ 971.

Piri, I., MoussaviNik, M., Tavassoli, A., Rastegaripour, F. and Babaeian, M. (2011). Effect of irrigation frequency and application levels of sulphur fertilizer on water use efficiency and yield of Indian mustard (Brassica juncea). Afr. J. Biotechnol., 10: 11459- 11467.

Pradhan, S., Sehgal, V.K., Das, D.K., Jain, A.K., Bandyopadhyay, K.K., Singh, R. and Sharma, P.K. (2014a).Effect of weather on seed yield and radiation and water use efficiency of mustard cultivars in a semi-arid environment.Agric. Water Manage., 139: 43 -52 .

Pradhan, S., Sehgal, V.K., Sahoo, R.N., Bandyopadhyay, K.K. and Singh, R. (2014b). Yield, water, radiation and nitrogen use efficiencies of wheat as influenced by nitrogen levels in a semi-arid environment. Indian J. Agron., 59: 267-275.

Pramanik, S.C., Singh, N.P., Singh, S. and Garnayak, L.M., (1996). Irrigation and nitrogen effects on oil yield and nitrogen uptake by Ethiopian mustard. Indain J. Agron.,41: 101-107.

Punia, S.S., Chahar, S. and Agarwal, S.K. (2001). Influence of crop geometry and nitrogen on seed yield and yield attributes of Ethiopian mustard (Brassica carinata). Indian J. Agron., 46: 732-745.

Ray, K., Sengupta, K., Pal, A.K., Banerjee, H. (2015). Effects of sulphur fertilization on yield, $S$ uptake and quality of Indian mustard under varied irrigation regimes. Plant Soil Environ., 61: 6-10.

Shabani, A., Sepaskhah, A.R. and Kamgar-Haghighi, A.A. (2013). Responses of agronomic components of rapeseed (Brassica napus $L$.) as influenced by deficit irrigation, water salinity and planting method. Intl. J. Plant Prod., 7: 313-340.

Sharma, R., Thakur, K. S. and Chopra, P. (2007). Response of nitrogen and spacing on production of Ethiopian mustard (Brassica carinata) under mid-hill conditions of Himachal Pradesh. Res. Crops, 8: 104-106.

Slatyer, K.O. (1967). Plant Water Relationships. 366p Academic Press, New York.

Yasari, E. and Patwardhan, A.M., (2006). Physiological analysis of the growth and devolvement of canola (Brassica napus L.). Asian J. Plant Sci., 5: 745-752.

Zarei, G., Shamsi, H. and Dehghani, S.M. (2010).The effect of drought stress on yield, yield components and seed oil content of three autumnal rapeseed cultivars (Brassica napus L.). J. Res. Agric. Sci., 6: 29-37. 